\title{
Designing Neighborhood for Communal Activities: Low-Rent Housing for Rural-to-Urban Migrants in China
}

Xueni Peng*

\section{Abstract}

Few researchers have observed the Chinese rural-to-urban migrants have the need to have communal activities to help them with the process of managing their spatial transition from the rural setting to the urban setting. This study investigates planning strategies regarding low-rent housing for Chinese rural-to-urban migrants through an examination of the intermediary spaces combined with functions shared among such Chinese migrants in their urban settlements. Chinese migrants gradually transfer from their home rural settlements to establish city lives and engage in urban occupations, but their sense of identity and family network remain grounded in a village culture. The high level of communal activities found in the spontaneous urban settlements of rural-to-urban migrants, can be understood as one aspect of the adherence to the lifestyle of their rural settlements. This research employs Canter's place model for organizing a data collection framework to understand the perception of high level of communal activities. As a
Keywords: Rural-to-urban Chinese migrants, the extended family, Low-rent housing, Communal activities, Transitional spaces, Shared functions

*Ph.D in Architecture department in Seoul national university, South Korea Email: E-mail: xueni.peng@gmail.com Orcid ID: http://orcid.org/0000-0002-6249$593 X$ 
result, this study is to show that the sharing of certain functions situated in the transitional spaces, namely, in front of the rental room, in front of the rental house and between the rental houses, must be joined with functions that residents can share or must share with each other. The shared functions situated in the transitional spaces actually allow communal activities to take root.

\section{INTRODUCTION}

The current trends of residential living in low-rent high-rise neighborhoods reveal that migrant tenants hold a different perspective on high-rise living. They expect a vibrant urban setting and close-knit communal activities with their neighbors. Rural-to-urban move are moving to modern low-rent high-rise apartments to update their living situation but this results in the loss of communal life that they had before. Moreover, the loss of communal life, more precisely, the lack of communal activities among residents reflects humans' withdrawal from traditional social structures.

While existing research on Chinese migrants' rental housing has dealt with the relations between low-rent and the poor situation of housing, their interrelationships with migrants' mental needs of communal activities are poorly understood. The current trends of residential living in low-rent high-rise neighborhoods reveal that migrant tenants hold a different perspective on high-rise living. They expect a vibrant urban setting and close-knit communal activities with their neighbors. Rural-to-urban move are moving to modern low-rent high-rise apartments to update their living situation but this results in the loss of communal life that they had before. Moreover, the loss of communal life, more precisely, the lack of communal activities among residents reflects humans' withdrawal from traditional social structures.

Analysis of this study suggests three points. Firstly, Chinese rural human's traditional social structures, mutual support, traditional extended family reflects migrants' need to have communal activities. It allows the continuation of rural migrants' lifestyle. Secondly, the high level of communal activities occurring in the transitional spaces mostly appertains to residents using the shared functions. These functions become a given condition that residents can share with other residents. Thirdly, all these shared functions provide a medium by which communal activities are actualized. The available shared functions help to build up the relationship of migrant residents to the functions of their choice, and also make it possible to generate communal activities among residents. 
This paper attempts to understand:

1. Need to have communal activities is important for Chinese rural migrants in low-rent housing

2. What are the causes of high levels of communal activity in migrants' spontaneously-developed low-rent housing?

3. How do the findings learned from this case study provide grounds for the future pattern of low-rent housing?

\section{IMPLICATIONS FOR THE NEED TO HAVE COMMUNAL ACTIVITIES FOR RURAL MIGRANTS}

The cultural differences between rural Chinese and urban Chinese are quite distinct. At this point, it is pertinent to revisit an image of the family in the eyes of the Chinese. Family, is in fact an extended family living under one protecting roof. In the Chinese countryside, until now this family type stands for the permanence of a family's full lineage (A. Xu, Xie, Liu, Xia, \& Liu, 2007). People in the countryside grow up and live surrounded by the group; they do not prefer to be alone.

In rural part of China, a high proportion of extended families with elderly parents living with their sons remains a distinct characteristic of the Chinese family today (Yu, 2013). The extended families are characterized by traditional family values, devoted mothers and fathers, and warm cooperative bonds with broader community. This extended living circle constitutes the typical adaptive mode of many cooperative, kin-based rural communities and contrasts with the individualistic strategies more common within the urban community (Graves \& Graves, 1974).

One role of a 'rural migrants' settlement' is to provide connection between migrants' rural background and their new urban background for generations of rural-to-urban migrants, and to have an influence on the transformation in their lifestyles (M. K. a. P. Whyte, W. L. , 1984). Many scholars question the positive assessment of the pattern of migrant settlements if governmentsubsidized low-rent high-rise projects are to be viewed as a great contribution (Cai, 2001; Chen, 1998; Jie \& Taubmann, 2002; M. K. a. P. Whyte, W. L. , 1984). They argue that the governmentsubsidized low-rent neighborhood design for a common good does essentially suggest that 'people living with dignity' (Tian, 2008) is to assume that a satisfied life is a shielded life (Fan, 2002).

Most of scholars concerning various aspects of migrants settlements have been dedicated to the procedures of the radical social change taking place in such accommodation while studies of Chinese low-rent housing rarely focus on the aspect of 
communal activities and its value for this specific residential group (Beja \& Bonnin, 1995; Xiang, 1993).

It is important to distinguish between migrants' low-rent neighborhoods and common neighborhood design. The Chinese cities look as if they deliver poor prospects for rural-to-urban migrants' integration into local neighborhood life (Bray, 2005; Read, 2003), except to the extent that they form a controversial migrant shelter/community (Zhang, Zhao, \& Tian, 2003; Zhu \& $\mathrm{Wu}, 2003)$ or gather in a urban villages, ChengZhongCun in Chinese (thereafter, CZC) as an adaptive feedback to discrimination (Chan \& Zhang, 1999). Some academic research, have recently contributed to the basic comprehension of several features of migrant accommodation (Chen, 1998; Piante, 1995; Su, 1996; W. Wu, 2002; Xiang, 1993). Most of them have concentrated on the progression of fundamental social changes happening in migrants' dwelling (F. Xu, 2008). However, few researchers have observed CZCs in urban areas with close knit communal activities. Despite this, some recent studies into communal activities have focused on urban residents in both middle-class housing estates (Li, Zhu, \& Li, 2012) and (more rarely) in rural-to-urban migrant communities (F. Wu, 2012).

In an earlier investigation, King et al (2000) true subject is the retirement from migration or migration for pursuing a better life, and Lipman (1971) showed us his consideration of architects' philosophy on community (Lipman, 1971). Well-organized city neighborhoods (no matter if they are for locals or for rural-tourban migrants) which match the life-styles of their residents and deliver communal activities for their inhabitants are able to nurture the emotional sense of togetherness that is decisive to mental well-being (Sarason, 1974).

As seen in scholars' studies, many low-income and working class people are content to live in so-called shantytown spaces as they have strong communal activities linked to their neighborhood areas (Gans, 1962; W. F. Whyte, 1943). Take the migrants' spontaneously-developed neighborhood for instance, the physically dilapidated neighborhood nurtures its individual subculture and a recognized 'lifestyle' which are shared by migrant residents (Zhang et al., 2003).

In rural settings where the individualistic effect is negligible or even absent, people still hold onto traditional values and put the family, village, farm and/or community in front of the individual. One role of a 'rural migrants' settlement' is to allow the continuation of rural migrants' lifestyle (Chung, 2013) or provide 
connection between migrants' rural background and their new urban background (Li, Zhu, \& Li, 2009).

Dwellings in urban areas give the impression of having no neighborly spirit or community identity. Whether urban residents have come from the working class or not, they are usually personoriented. Their living preference generally depend more on how well they can protect their privacy, create a sphere of privacy, and live in an environment that shields residents from multiple stresses and disturbances. However, for rural migrants, their living strategies are based on a close network, and even though they have settled down in cities their geographical location is a kinship or peer-group membership-gathering space.

A truth that the planning standards which are applied to the current public low-rent housing cut the maintenance of the migrants' lifestyle, it actually imitates the value pattern of middle class specialists. These expectations, belonging to designers, allocate an autonomy or privacy-based value to housing greater emphasis on 'living in the housing' than 'living in the neighborhood'. Designers' evaluation of low-rent housing is based on their urban-defined standards and provides services founded on their values.

The following study, I try to investigate the level of communal activities in the rural-to-urban migrants' spontaneous-developed settlement in Beijing city of China. Migrants' neighborhoods can virtually be considered as Chinese rural cultural territories. One example of this is the Yimuyuan community, it is one of the biggest migrants' spontaneous-developed housing areas in Beijing.

\section{METHODOLOGY}

Referring to Canter's place model, to achieve a livable and meaningful place, three dimensional experiences of places are emphasized (Canter, 1977) They are: (1) spatial structure, (2) activities and (3) perception. Those three components, then, are not separate features in a place, but inter-connected elements that help to generate a place. By means of this connection of three components in a place, Canter clarifies how this place model can arise in an examination of urban redevelopment. When urban redevelopment causes major changes in spatial characteristics and those changes can be identified, meanings in relation to those spatial alterations can be recognized and people's activities can be tied to the spatial changes and in doing so various meanings in the place can be identified. 
This study uses Canter's place model for forming data collection framework to understand physical characteristics and to find practical evidence for comprehending the residents' communal activities in rural-to-urban migrants' low-rent housing neighborhoods. To triangulate this study of transitional places in the low-rent housing, each component in Canter's place model can be used to support elucidation of the level of communal activities and the awareness of place vitalization in these migrants' low-rent neighborhoods. The study attempts to examine migrants' communal activities through questionnaires and interviews. Also, in the context of migrants' low-rent neighborhood development, this research of migrants' regular gatherings seeks to learn people's perceptions based on the environmental settings. The migrants' views were gathered by conducting a survey which comprised a qualitative method and some quantitative methodology. In a succeeding survey, questions about communal activities and neighboring were involved in closed and openended answers.

Such settings and the characteristics of the typical rural-to-urban migrant housing and neighborhoods are the chief subjects for comprehending how migrant users observe communal activities and why the different perceptions emerge in their neighborhoods. This research uses three important levels of man-environment relationship which are essential components for comprehending the communal activities in migrants' low-rent housing neighborhoods. They are:

1. Spatial structure: what the physical parameters of that setting are (I draw layouts of spatial characteristics and schematic diagrams of the spatial elements from my own living experience and daily field-observations)

2. Activities: what behavior is associated with, or it is anticipated will be housed in, a given locus (I Map the kinds of daily residential activities and observing residents' communal activities in the corresponding spatial environment)

3. Peoples' perception: the descriptions, or conception, which people hold of that behavior in that physical environment (I draw cognitive images from residents and fill out questionnaires and the interviewing of residents)

The research method was based on my own living experiences, field observation and questionnaire survey and was developed to allow the empirical study to be done in a clear, objective, and replicable manner. The results of the analyses in relation to the spatial pattern of the low-rent spaces and the corresponding communal activities are shown. 


\section{CASE STUDY: CHINESE RURAL MIGRANTS' SPONTANEOUSLY- DEVELOPED NEİGHBORHOOD IN THE YIMUYUAN IN BEIJING CITY}

Yimuyuan low-rent neighborhood is a distinctive character as a case study (Figure 1) because it has already been designated as a migrant enclave, in which the biggest desirability included the low cost of accommodation and consumption in Beijing city of China.

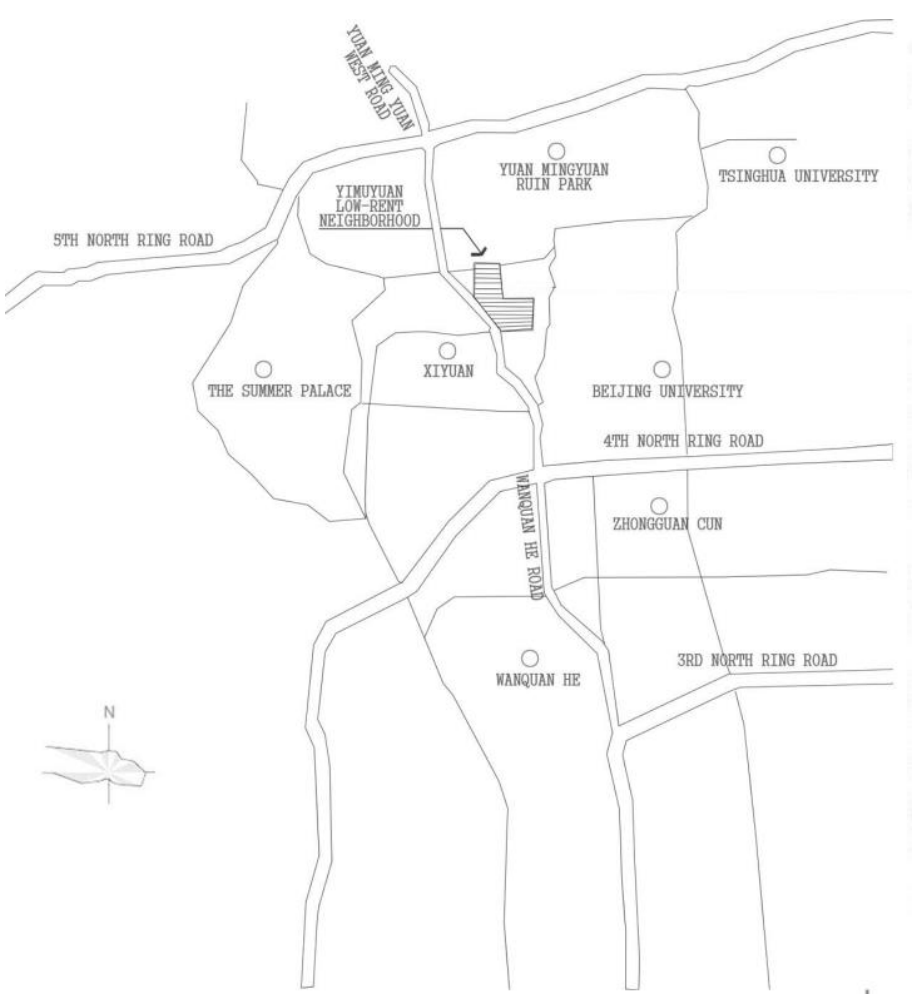

The spatial structure

Migrants' rental room

Figure 2 supply representative features of Yimuyuan housing can best be explained by my drawing. To begin with, private low-rise houses are scattered as a common village neighborhood. Since the house owners decided to transform their normal houses into the rental rooms, the most major transformation was the maximum simplification of functions in the housing. The normal functions in private housing (family-gathering, playing, cooking, cleaning) have been completely taken away and replaced by a collection of bedrooms of different size.
Figure 1. The location of Chinese rural migrants' spontaneouslydeveloped housing in the Yimuyuan in Beijing city (Drawing by author) 


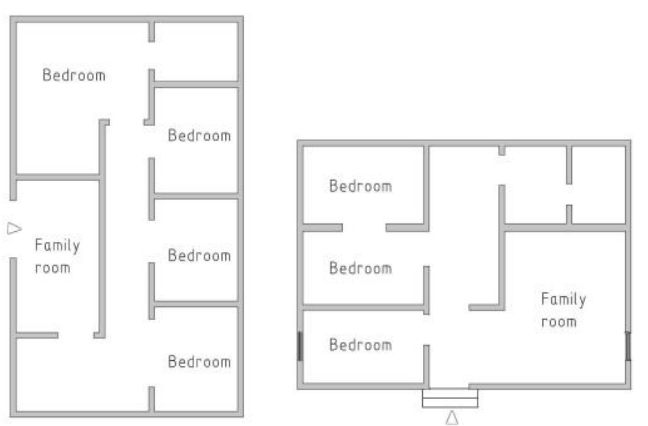

Before being rearranged into the rental rooms

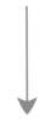

After being rearranged into the rental rooms

Figure 2. Comparison drawing of the before and after rearrangement of rental rooms by local landowners in Yimuyuan neighborhood (Drawing by author)
Figure 3. A room layout of single tenants in Yimuyuan neighborhood (Drawing by author)
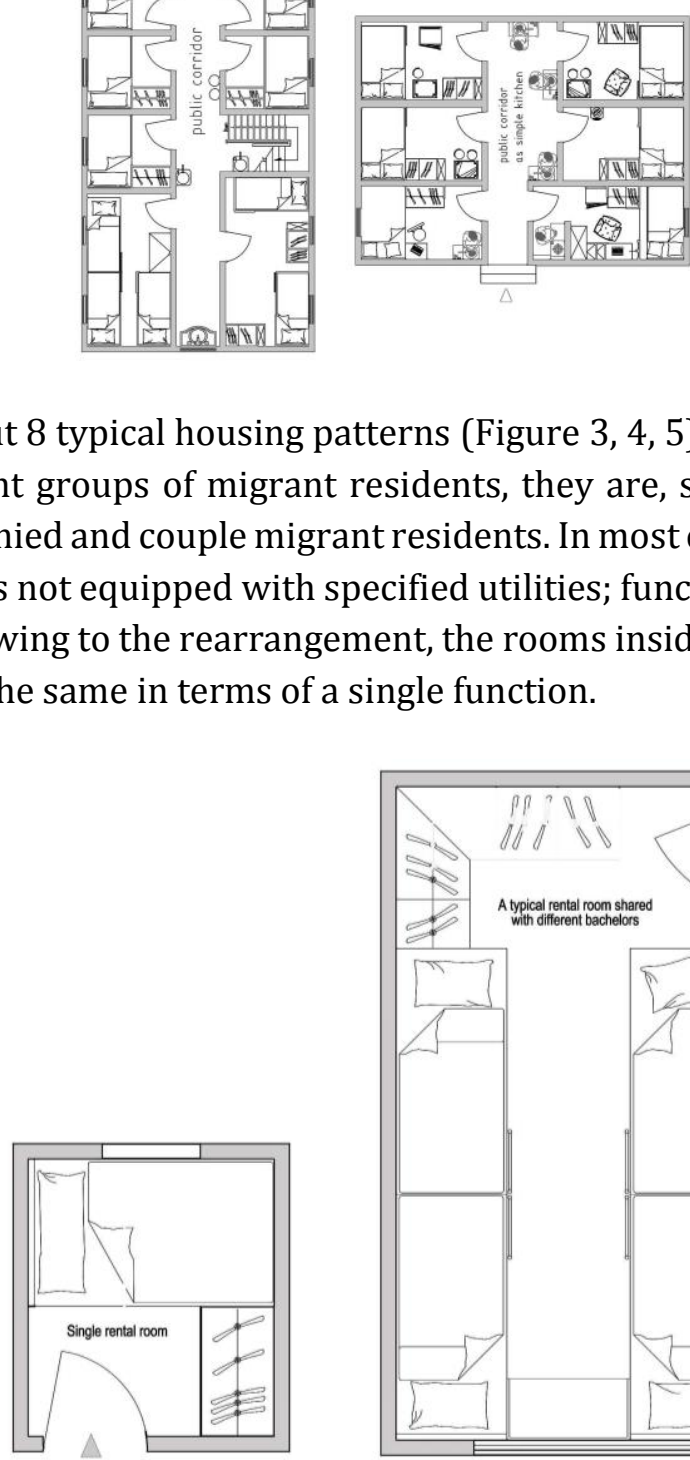

I drew out 8 typical housing patterns (Figure $3,4,5$ ) according to 3 different groups of migrant residents, they are, single, familyaccompanied and couple migrant residents. In most cases, a rental room was not equipped with specified utilities; functions were all mixed. Owing to the rearrangement, the rooms inside the housing became the same in terms of a single function.

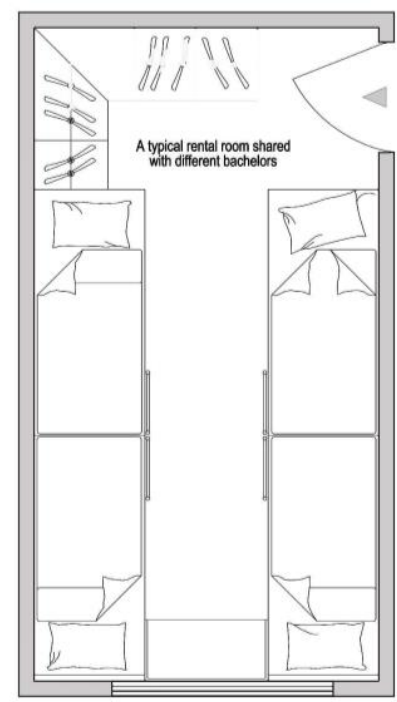



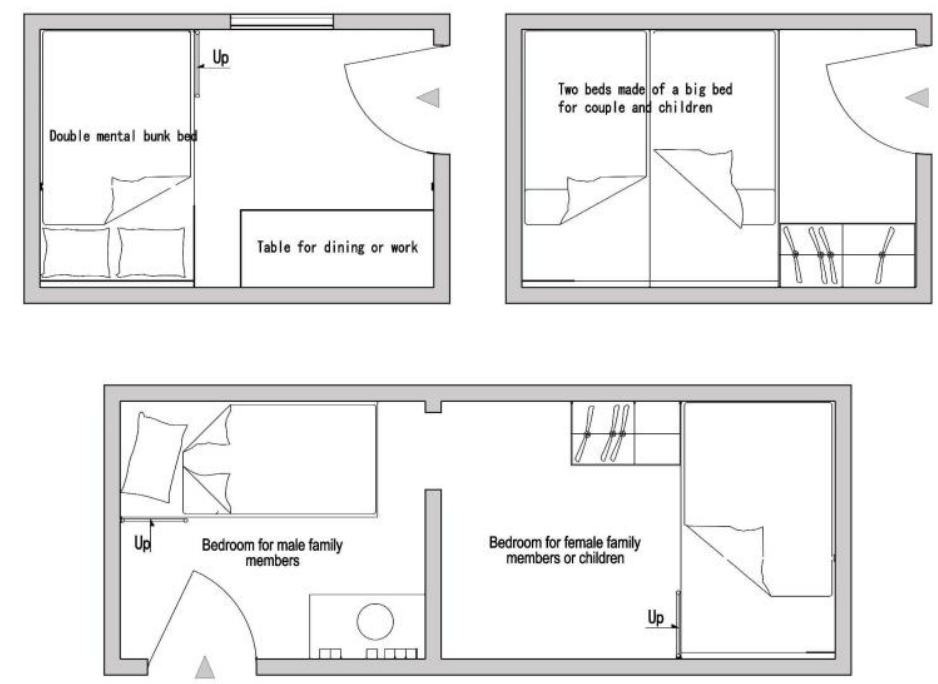

Figure 4. A room layout of parentaccompanied migrants in Yimuyuan neighborhood (Drawing by author)

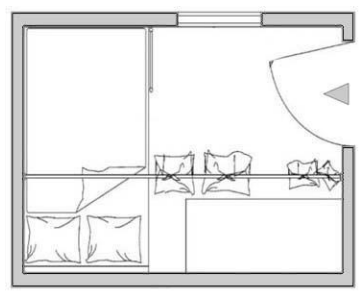

(Type A)

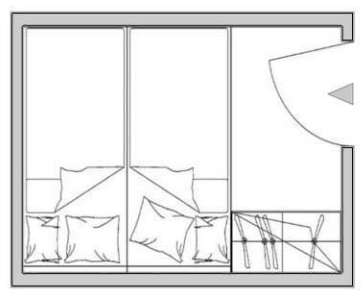

(Type B)

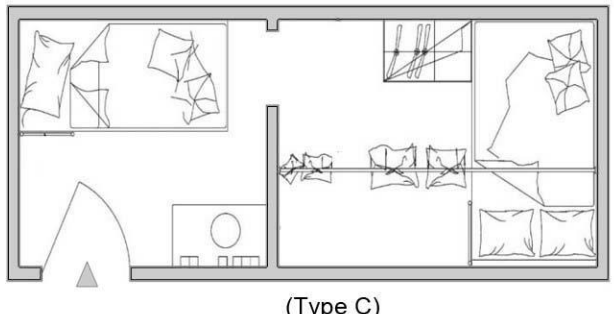

Inside of the housing, the corridor served as a spatially distinctive entry place to the interior spaces. The function of the corridor inside of the house is expanded unconsciously in terms of its location and its function as an access point connecting inside and outside. The other characteristic of the latter houses in Yimuyuan neighborhood is, the space in front of each single rental room in a corridor extended as an individual property area for private living-related use. Between the rental rooms, the front of the rental room might have enabled the migrant residents to use as another major living space to make up the lack of private space.

Actually, couple migrant residents are inclined more to the functionality of their living quarters, having a separate kitchen and a lavatory. A typical rental room consists of one living room with an adjoining separated small space for cooking fuel. Truly, these service quarters were not planned as a necessary part in most of the migrants' settlements. More than half of the rental rooms in the Yimuyuan neighborhood had simple access to a

Figure 5. Typical room layout of sampled couple-only tenants in Yimuyuan neighborhood (Drawing by author) 
cooking stove, including a poorly maintained cooking facility in front of their rental room or at best a shared cooking facility on the bottom floor of the whole building. Narrow corridor is always crammed with cooking utensils, shelves and a drying rack.

\section{Migrants' rental house}

After 1987, the local residents gradually recognized that renting was enormously money-spinning. So an increasing number of families got used to living under the same roof with rural-to-urban migrants. So this regional area occupies the rental rooms (Figure $6)$.

Figure 6. The schematic diagram of changes of house plan in Yimuyuan neighborhood (Drawing by author)

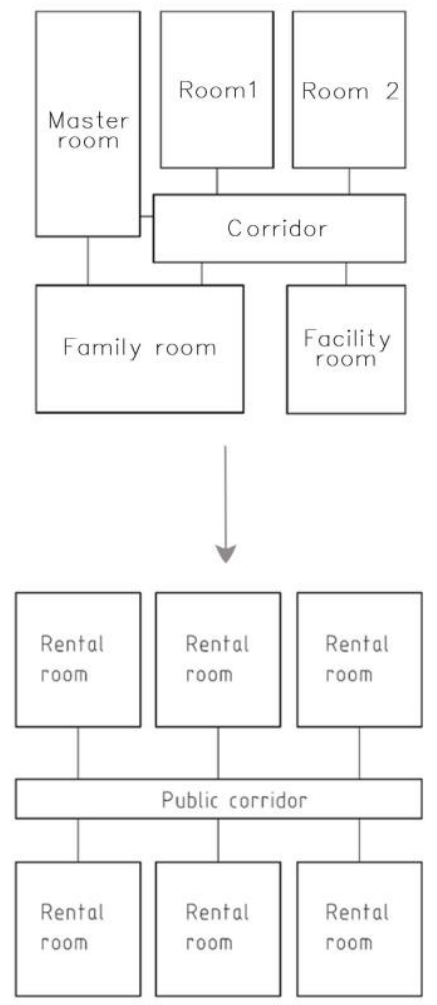

Front stoops, sidewalks and many other forms of transitional spaces, between the house and the communal alleyway or lane, are characteristic surroundings around the rental house. Whereas the inside of the rental room looks like being a space into which private activities overflowed from inside the house, the space at the front of the house logically has formed a barricade between the privacy of the room and the completely communal feature of the adjacent houses in the neighborhood, as well as a connection between the small social group of different person/families and the larger social group of the community.

Between the rental houses 
Personal, regular household work, daily-used shared infrastructure and leisure/social entertainment are the main focuses of the communal activities (Figure 7). In the Yimuyuan area, because the rental rooms have extremely simple functions, so the people need to depend on the outside spaces and public facilities to take care of themselves. The facility place is detached from the main body of the rental house, and served as a part of the neighborhood instead of as a part of inside of the rental house.
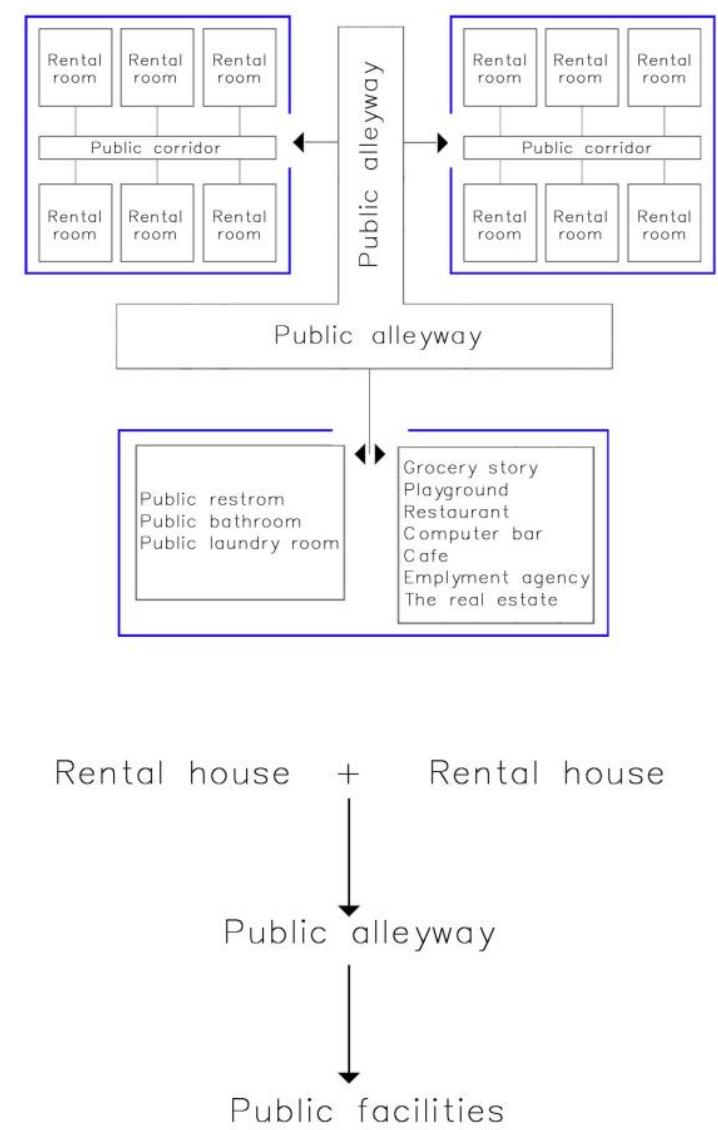

Thus it can be said that the space between the rental houses maintains important migrant-support functions of the normal house, and so becomes an integrated part of the house. The whole neighborhood becomes an intertwining set of 2 forms of function categories. They are labeled as 'necessary function', and 'migrants-support functions'. These functions help to build up the relationship of residents to the function of their choice, and also enable a relationship to form among residents. Consequently, functions of sharing create communal activities, for instance, the cooking, cleaning, the bathing, laundry as necessary provided functions are shared by the whole residents. This characterizes the role of the public alleyways between the rental houses in fostering communal sharing.
Figure 7. Schematic diagram of set of functional network in Yimuyuan neighborhood (Drawing by author) 
A five-story tenement is the main building type. These buildings are small and several houses had to share bathroom and toilet facilities. Residential streets, the corners and sidewalks, and small scale open spaces such as play grounds, courtyard are major physical environment for the space between the rental houses in the Yimuyuan neighborhood. Computer rooms around the corner, front of the corner stores, restaurant and other social places are the other situations between the houses. Walking through the neighborhood, the phenomenon of using these public functions as an individual's extended home ground can be named as the 'domestic territory function'.

\section{The Migrant Residents' Activities}

Three patterns of spatial environment serve migrants conduct their communal activities. They are: front of their rental room, the open space front of their rental house and their neighboring small blocks. The three spaces result in residents' three types of activities, such as a necessary activity, a transitional activity and a social activity.

Front of migrants' rental room

The most dominant function in front of migrants' rental room in the Yimuyuan neighborhood is to serve as a cooking/storage activities (Figure 8, 9, 10). The narrow size of rental room enables the migrant residents to use the space in front of their room as a supplementary living space (for cooking, cleaning, stuffgathering). Between the rental rooms, the corridor has enabled the residents to use it as kitchen.

Figure 8. Schematic diagram of arrangement of migrant tenants' public corridor as kitchen in front of their room (Drawing by author)
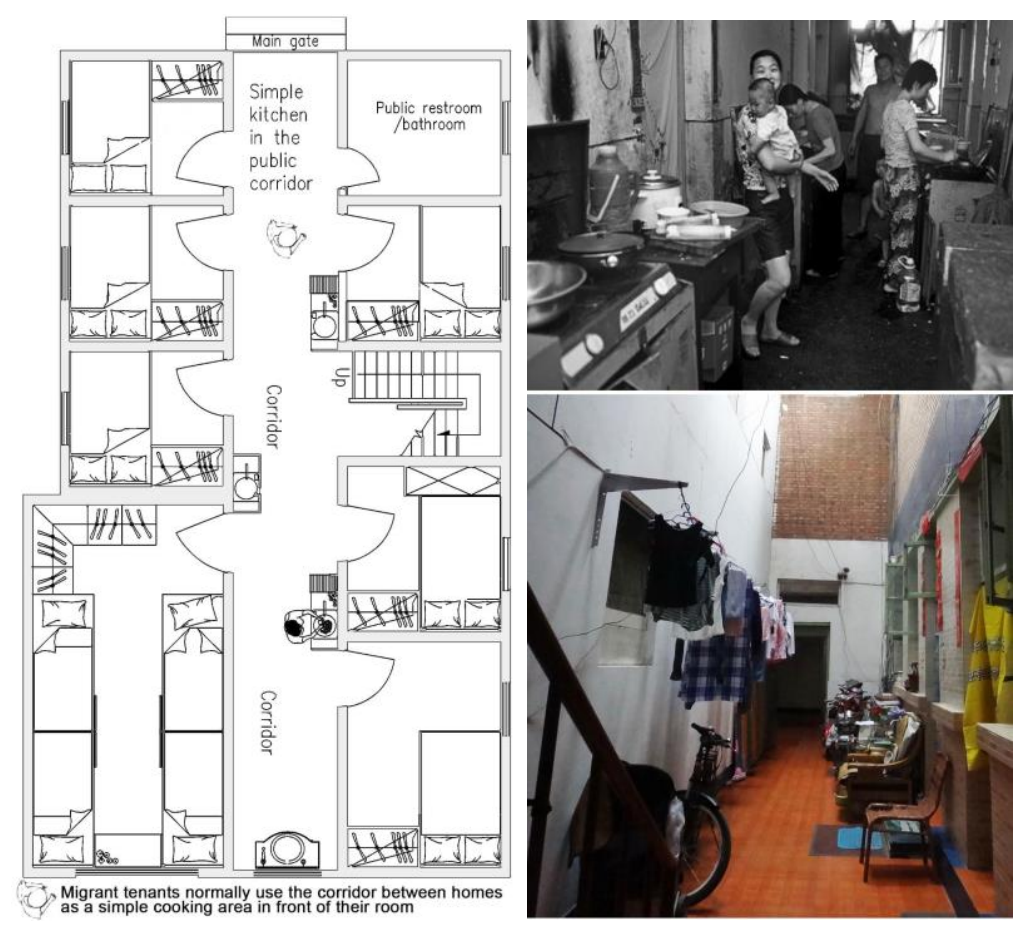

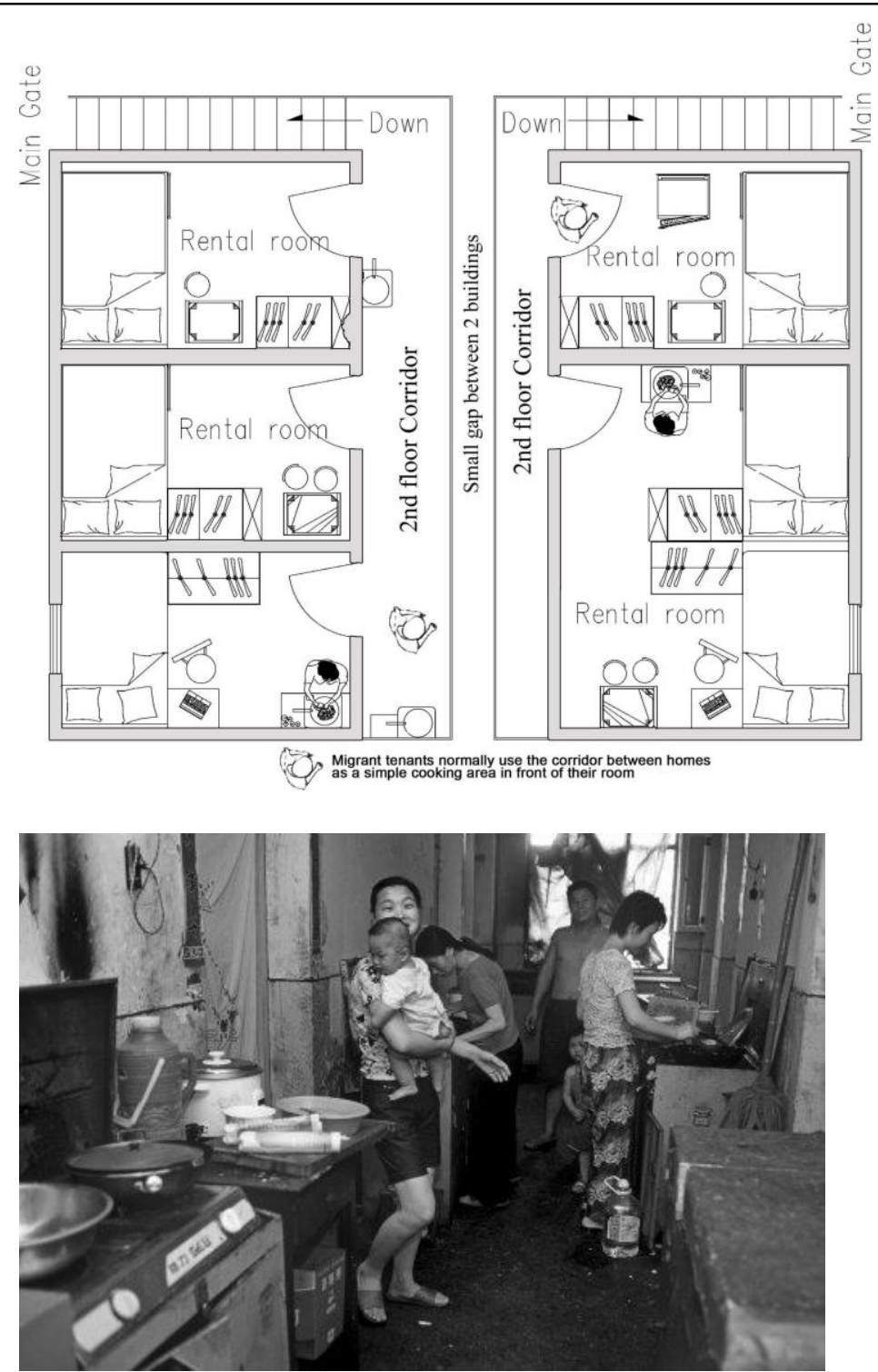

The rental room in the Yimuyuan, strictly speaking, is a public home, not a private residence. Physical evidence of the typical forms of rental room environment-heavy use of private space and extended private space in the public corridor. When the inside space gets busy or stuffy, family members use their public corridor often to satisfy the spatial inadequacy, and carry on their activities near their rental room door. The seemingly diverse purposes of each room come together inside of the rental house due to the willingness for communication. When preparing daily things, the corridor is used for other constant daily usage. So, there is no effort to stress the need for private living compartments. Many members, nuclear families, generations living within rental room(s), their natural activity level regarding cooking housework actually happens in the corridor, in front of their rental room. This is the most significant of household activities where the communal activities take place.

Figure 9. Schematic diagram of arrangement of migrant tenants' public corridor as kitchen or storage space in front of their room (Drawing by author) 
Figure 10. Schematic diagram of arrangement of how migrant tenants' public corridor as storage space in front of their room (Drawing by author)

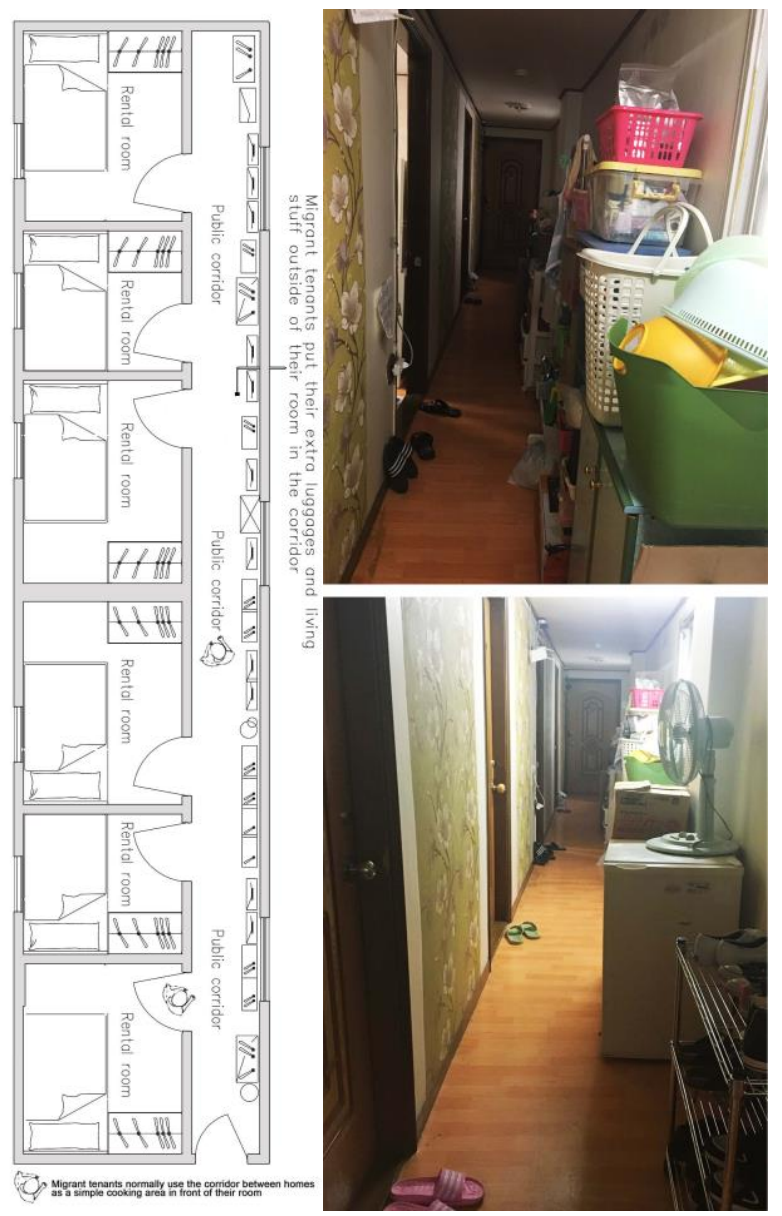

A simple kitchen in the public corridor is not in a minority option. A corridor of $1.5 \mathrm{~m}$ wide, is composed of minimal cooking furnishings. One stove and one table are set for meeting the minimum requirements of simple cooking. The location of food preparation could be considered as being at the very core of the house. In the Yimuyuan neighborhood, this core location is seldom placed inside of a private rental room, but it cultivates a shared feeling. Cooking and housework are not just solitary activities performed by a person or family members together. These functions are the background through which self-enclosed individualism is conquered in support of an empathy that nurtures collective sharing, cooperative measures.

Under these conditions, the neighborly communication for residents starts from in front of their room. The cooking function combined with a corridor during a day is shared by the group of people who reside in the same floor. The cooking, and storage functions serve as the character that describes the relationship between residents and space, the relationship between the sharers. Cooking and storage have both a spatial character and a character of the inter-residents.

Front of migrants' rental house 
(Figure 11) In the Yimuyuan neighborhood, the residential housing includes the most traditional form of Beijing residential housing-the Pingfang (bungalow) and low-rise houses. The Pingfang houses are normally equipped with more adjacent rooms on all four sides around the courtyard. The strong association between the place in front of the rental house and the residents is simply expressed in two activity patterns that are dominant in the process of forming the intimate communal spaces. They are: use of water facilities by residents and drying clothes on ropes and bamboo pipes in the narrow alley front.

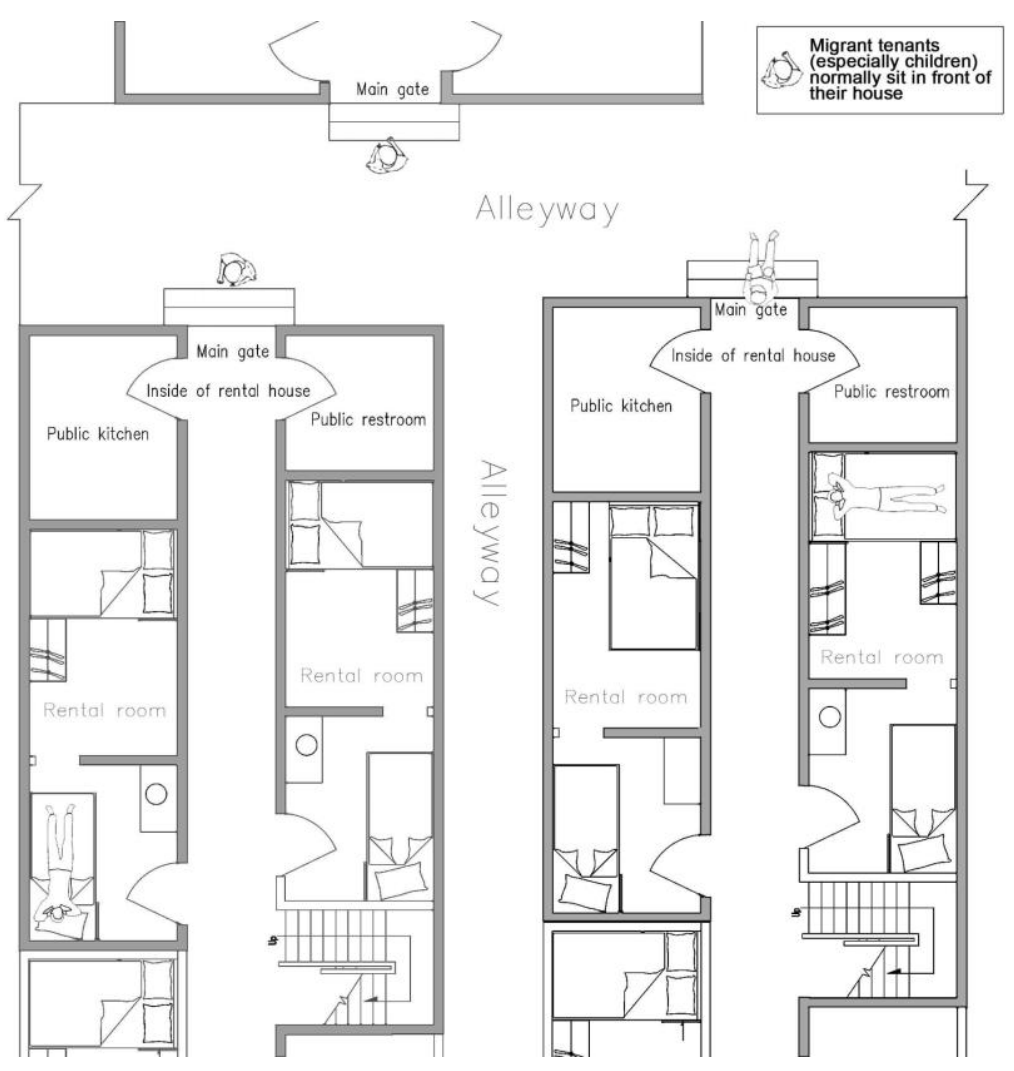

Normally in their daily context in front of residents' rental houses, activities are rarely done by one person on their own. When this does come about the resident will all the time invite others present to be with him/her. This invitation is an emblem of hospitality and inclusion. It is significant that the working on laundry, sitting, taking of foods or drinks, spending time in front of the rental house are a normal part of daily visiting for residents living in the Yimuyuan.

Residents minimize the connection between specific areas of the neighborhood and men or women, saying 'it is not calculated', strictly followed. It is difficult to ascertain whether such integration is more observed in the Yimuyuan than elsewhere. A facility-based spatial hierarchy is particularly clear in the relations between in front of the rental rooms and in front of the
Figure 11. Schematic diagram of arrangement of migrants' use space in front of rental house (Drawing by author) 
rental houses, but between the houses most communal facilities and services are shared.

In the Yimuyuan houses, most of the water comes from a public pump in the street, normally outside of the house, residents fetch water, do minor laundry (for major clothes washing they use a public laundry room nearby), and perform other chores. Food preparation occupies a lot of time, because of the location of their water they spend a great deal of time outside of their house. Residents' own perception of communal activities is that they are rather occasional, its daily necessities. In the Yimuyuan neighborhood, different areas of the rental neighborhood have a tendency to not be strongly associated with particular people but linked with specific spatial utilities.

Co-resident nuclear families have an extended area existing in front of the house for their household use. Household members do, however, have their customary household space either in the corridor or the street in front of their rental house, where these are all functionally a part of its interior. The door of each single rental room extends to the interior space, the entrance of the related housing functions as division between inside and outside. The residents are 'at home' inside of the house instead of just inside of their own room.

Between the rental houses

The space between the rental houses provide activities such as simple gymnastic, karaoke, games, and playing music, as well as support the elderly residents. In this facility, the migrant residents create companionship between each other. These activities are not a responsibility to be followed by the migrant residents who dwell in the neighborhood, rather they are provided for those who want and need activities.

The alleyway in front of the rental house is likely to be more public than corridor in front of the rental room, and communal activities occur in the corridor within relations of next-door neighbors. Between the rental houses, the space refers to a neighborhood place which is not legally owned by specific people, but under certain circumstances, is occupied and used exclusively to produce a collective-symbolic ownership for a certain group of people (Figure 12,13). Corner grocery stores, markets, public restroom, public bathroom are the main settings for meeting tenants' everyday necessities. In other words, the activities in which those involved are to a greater or lesser degree required to participate. 

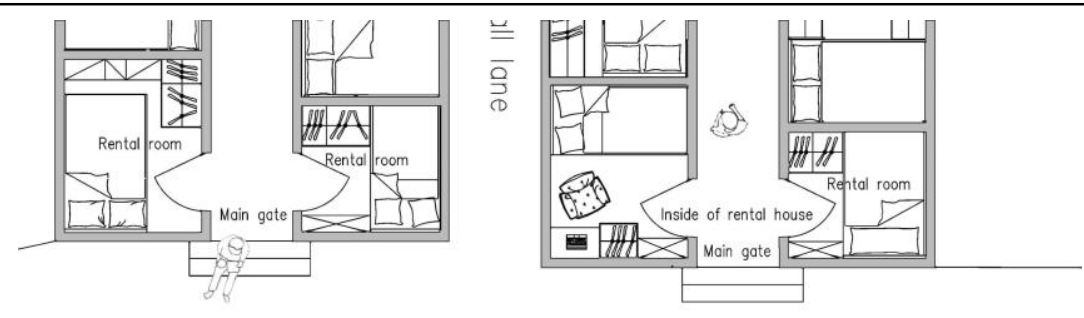

Street

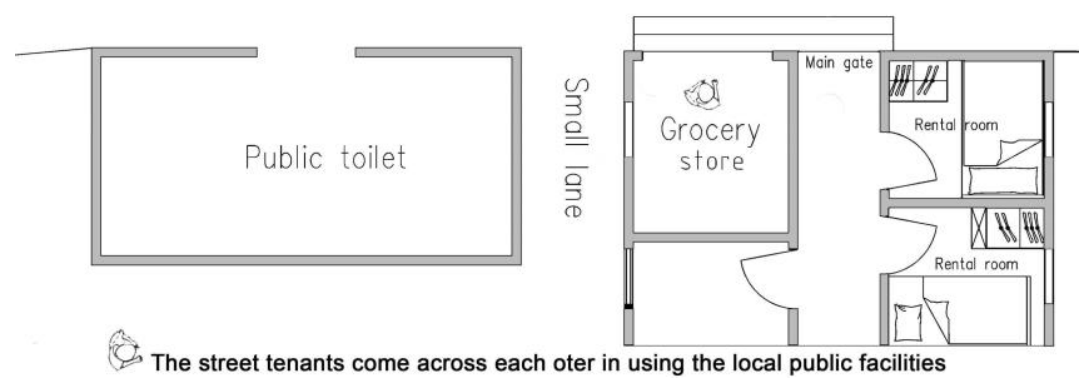

Figure 12 shows the diagram of a typical situation of tenants' social interaction around the public facilities (public restroom) in the Yimuyuan neighborhood. The basic layout is quite simple. When I asked some residents the street name or the name of one restaurant, they answered: that they didn't know exactly, here there is no exact name for each small alleyway or corner. People use their own ways to recognize places. For example, somebody's house.
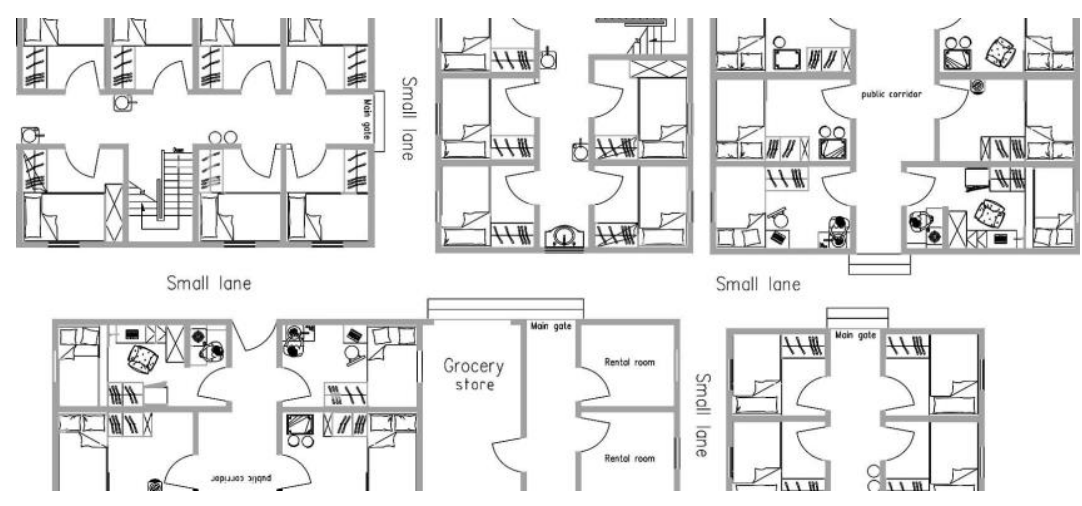

Small lane
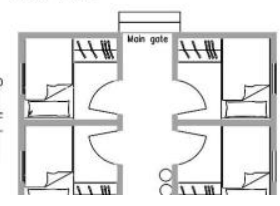

In residents' minds, they associate Yimuyuan with the people there instead of the place itself. For example, a housewife, one of my interviewee, although she has lived in here for almost 5 years, she always says, Yin's house or Min's rental room instead of using the exact name of the alley. Because people recognize this neighborhood through the people they know. They go to these places to meet them.

In the Yimuyuan, radios and stereo players are listened to at a very high volume, and television sets are always located near the window. Both forms of leisure are shared with neighbors. Radio and television and gossip are the main source of recreation and
Figure 12. Schematic diagram of arrangement of space of between the rental houses (Drawing by author)

Figure 13. Schematic diagram of arrangement of space between the houses (Drawing by author) 
information about what is happening around the city (especially for a migrant's wife). The streets are not calm in the morning either. Most migrant residents are also running small business, morning is their busiest time for preparing. On a hot summer day, they take good care of the space in front of their rental house by sprinkling water to settle the dust.

Although the rental room in the Yimuyuan leads to minimizing privacy, this may in turn, foster an atmosphere that boosts the desire to dedicate dwellers' time to being spent with others. Since the ground floor serves as the best communal gathering place for amusement and handling business, all dwellers spend their time on these public activities. Individual pursuits are customarily disregarded in contrast to the welcome given to public spaces, but both of them are filled with the soul of impartiality and community.

\section{The Migrants' Residential Perception and Survey}

From a cognitive point of view, migrant residents' cognitive image becomes an index of their communal activities. Migrant residents were asked to list places that they considered to be related to their daily life in the Yimuyuan area. I seek to discern how residents perceive their communal activities in relation to their everyday experiences.

Cognitive image of rural-to-urban migrants

(Figure 14) $\mathrm{Xu}$ who is one of the Yimuyuan migrant tenants who lives in and works in this area. Xu's image map presents he understands his (his family) communal activities in relation to supporting their lives of working and living. The majority of time I met Xu for this interview and their informal talk was conducted either in their rental houses or at their stalls while they worked. $\mathrm{Xu}$ and his wife rented a big room on the first floor in the Yimuyuan as their business place. They worked together every day, opening their restaurant at 5:00am and closing it at 6:00pm. Customers are almost all from the Yimuyuan neighborhood. 
Designing Neighborhood for Communal Activities: Low-Rent Housing for Rural-to-Urban Migrants in China

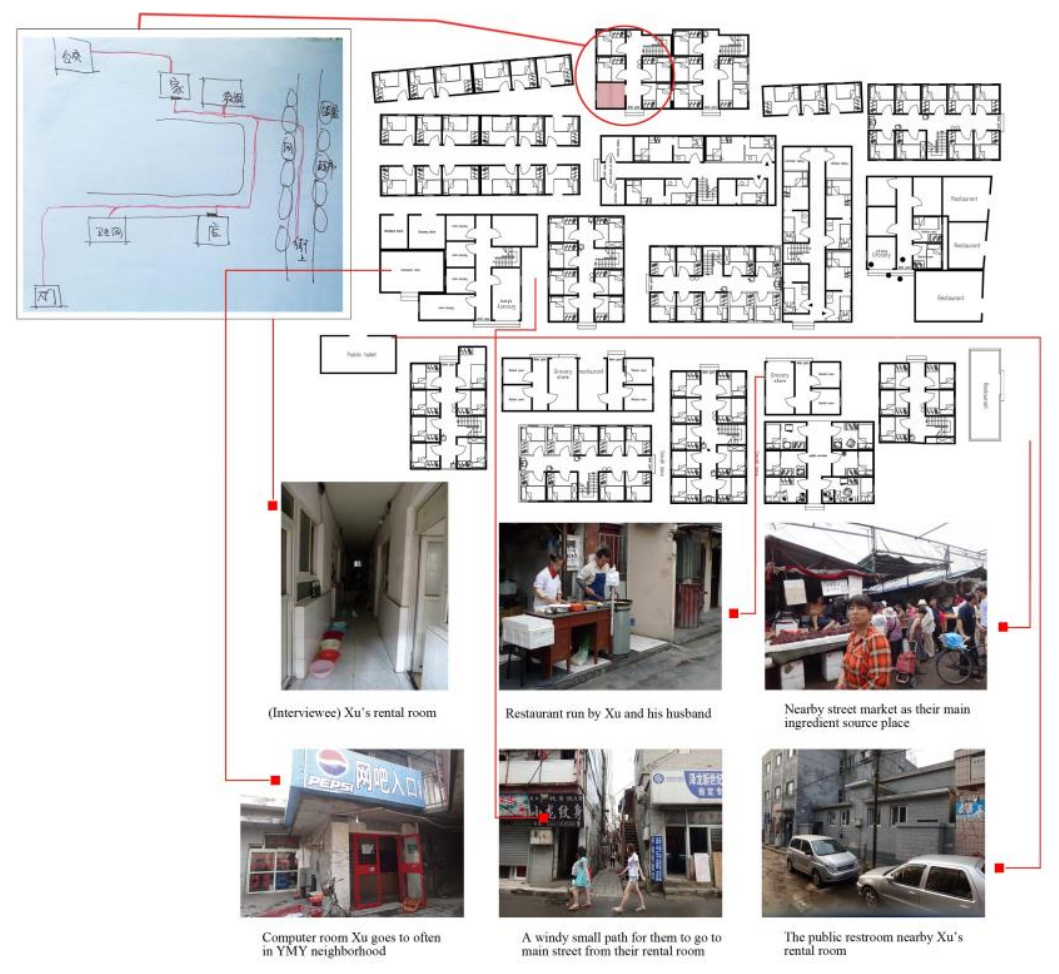

During my interview, they showed they have an image of the Yimuyuan area based on the composite elements in the built-up environment near their rental room, the business they make, people they met and the daily sources they use. They focus on these elements of the living environment which marks it as a close knit web of communal activities.

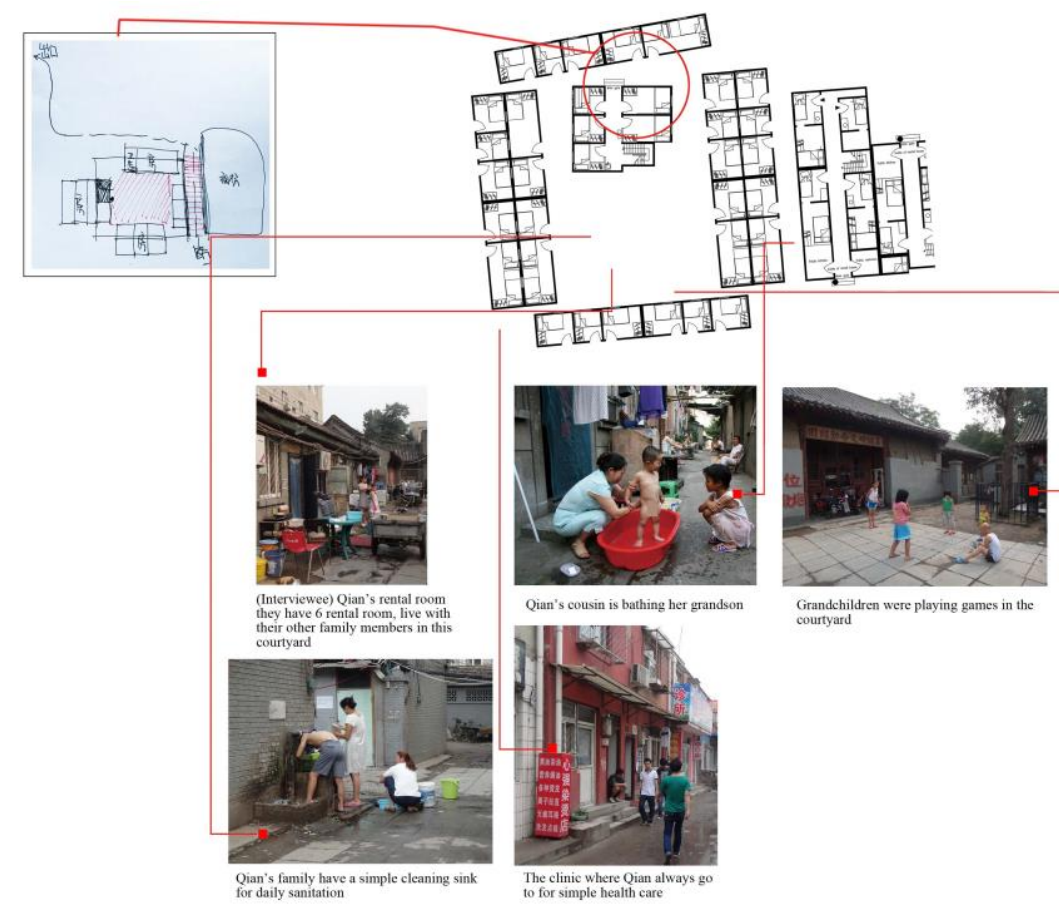

(Figure 15) The second cognitive image is from familyaccompanied migrant resident, Qian. After migrating to Beijing
Figure 14. Cognitive image of Yimuyuan neighborhood by a ruralto-urban migrant, Xu (Drawing by author)

Figure 15. Cognitive image of part of Yimuyuan neighborhood, Qian (Drawing by author) 
city, she and her extended family (3 generations) live together in the Yimuyuan neighborhood. It is striking that her understanding of communal activities is on an inter-personal level. Her image is an example of the perceptions of communal activities by communication through face to face within small physical boundaries.

Qian draws major activities among their daily life. She locates her activities within her adjacent environment. Moreover, her everyday life is not spent alone, but is accompanied with the locals, family members, and neighbors. She explains that her daily life in the Yimuyuan neighborhood looks like the previous life she lived in her hometown. Qian's image map shows that she understands her (her family) communal activities in relation to the washing clothes, bathe her little boy, sitting, taking of foods or drinks, with families and neighbors.
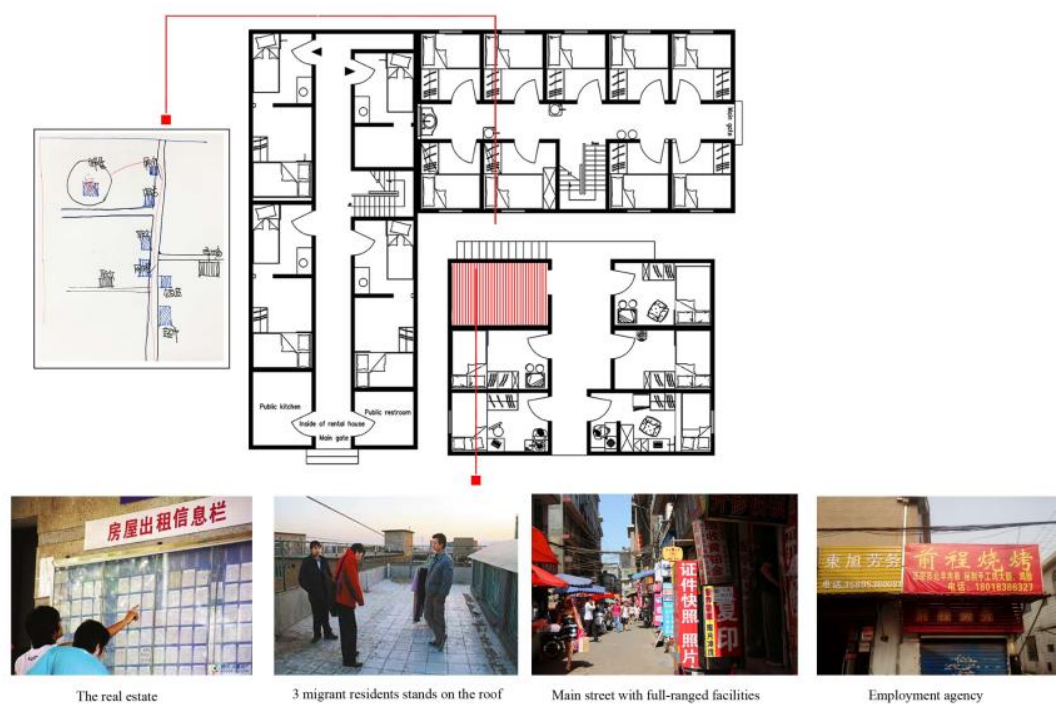

Figure 16. Cognitive image of part
of Yimuyuan neighborhood, Kang (Drawing by author)

(Figure 16) During my interview, single migrants occupied the greatest ratio of residents living in the Yimuyuan neighborhood. They mentioned they started their migration life before they finished their high-school education. Actually, dense accommodation and sharing places provide emotional support to one another. Their knowledge of Yimuyuan life is rooted in personal necessities and daily life. A migrant tenant said that:

Beijing local people are all cold treating migrant workers. Yimuyuan is a good place for migrants to live together.

A 17-year-old girl tenant surveyed said:

The neighborhood is a small world in which has a full range of everyday activities that can be conducted without dependence in the outside environment. 
How they understand their communal activities as is the relationship between spatial cognition and residents' activities present residents' communal activities as not isolated with places, but being closely related to their daily necessities and sharing these daily supplies.

I examine qualitative interviews conducted on 2013 with 45 ruralto-urban migrant residents who live in the Yimuyuan CZC, to illustrate their communal activities integrated within their neighborhoods. These 45 interviews, while not representative of all rural-to-urban migrant residents, provide insights into the close relationship between spatial planning and residents' participation level of communal activities. In Table 1 and 2, it informs us of the general statistics of the three communities of migrants. The questionnaire, consequently, was made in such a way that the responses could elucidate migrant tenants' perceptions of their neighborhood in addition to supplying information regarding their forms of neighborhood area usage.

Table 1. General statistics related to community experience of the three groups (source: Yimuyuan community survey in 2013

\begin{tabular}{|c|c|c|c|}
\hline \multirow{2}{*}{$\begin{array}{l}\text { Measurement value of sense of } \\
\text { community }\end{array}$} & \multicolumn{3}{|c|}{ Migrant type (15 people in each group) } \\
\hline & $\begin{array}{l}\text { Parent-accompani } \\
\text { ed migrants } \\
\text { (above } 15 \text { old) }\end{array}$ & $\begin{array}{l}\text { Single(unmarr } \\
\text { ied) migrants }\end{array}$ & $\begin{array}{l}\text { Couple-only } \\
\text { migrants. }\end{array}$ \\
\hline \multicolumn{4}{|c|}{$\begin{array}{l}\text { Number of friends and/or relatives in this neighborhood (Number of interviewer, } \\
\text { present } \% \text { ) }\end{array}$} \\
\hline Nobody & $1(6.7 \%)$ & $0(0 \%)$ & $0(0 \%)$ \\
\hline $1-3$ & $2(13.3 \%)$ & $3(20 \%)$ & $4(26.7 \%)$ \\
\hline $3-5$ & $5(33.3 \%)$ & $8(53.3 \%)$ & $6(40 \%)$ \\
\hline $5-10$ & $3(20 \%)$ & $2(13.3 \%)$ & $4(26.7 \%)$ \\
\hline \multirow[t]{2}{*}{ More than 10} & $4(26.7 \%)$ & $2(13.3 \%)$ & $1(6.7 \%)$ \\
\hline & $15(100 \%)$ & $15(100 \%)$ & $15(100 \%)$ \\
\hline \multicolumn{4}{|c|}{$\begin{array}{c}\text { Sequence of place where migrants meet their neighbors and relatives living in } \\
\text { this area (present \%) }\end{array}$} \\
\hline In your rental room & 6.1 & 10.2 & 4.1 \\
\hline In the front area of your room & 20.2 & 24.1 & 23.3 \\
\hline In the public kitchen & 7 & 20.2 & 26.2 \\
\hline In the public bathing room & 14.2 & 18 & 10 \\
\hline Front street of your house & 22.3 & 13.3 & 23.1 \\
\hline In a local market or restaurant & 5.1 & 9.1 & 4.2 \\
\hline $\begin{array}{l}\text { Parks or other facilities within } \\
\text { neighborhood }\end{array}$ & 12 & 4 & 5.1 \\
\hline Some streets within few blocks & 13.1 & 1.1 & 4 \\
\hline \multicolumn{4}{|c|}{ Neighborly Relationship (present \%) } \\
\hline Sociability & 68.1 & 65.8 & 49.3 \\
\hline Common assistance & 70.3 & 65.2 & 62.5 \\
\hline Mutual trust & 69.8 & 50.1 & 45.9 \\
\hline Acquaintance & 68 & 55.5 & 50.4 \\
\hline \multicolumn{4}{|c|}{ Attention to the Community Involvement (Number of interviewer, present \%) } \\
\hline Not pay attention & $2(13.3 \%)$ & $1(6.7 \%)$ & $3(20 \%)$ \\
\hline Pay a little attention & $8(53.3 \%)$ & $10(67 \%)$ & $10(67 \%)$ \\
\hline \multirow[t]{2}{*}{ Pay much attention } & $5(33.3 \%)$ & $4(26.7 \%)$ & $2(13.3 \%)$ \\
\hline & $15(100 \%)$ & $15(100 \%)$ & $15(100 \%)$ \\
\hline \multicolumn{4}{|c|}{ Community Belongingness (Number of interviewer, present \%) } \\
\hline Merely provisional dwelling & $2(13.3 \%)$ & $1(6.7 \%)$ & $3(20 \%)$ \\
\hline Hard to tell & $5(33.3 \%)$ & $6(40 \%)$ & $3(20 \%)$ \\
\hline \multirow[t]{2}{*}{$\begin{array}{l}\text { As a real home (a place where } \\
\mathrm{I} / \text { we belong to) }\end{array}$} & $8(53.3 \%)$ & $8(53.3 \%)$ & $9(60 \%)$ \\
\hline & $15(100 \%)$ & $15(100 \%)$ & $15(100 \%)$ \\
\hline \multicolumn{4}{|c|}{ Reason to stay in this neighborhood (present \%) } \\
\hline Cheap rental room & 56.5 & 85.4 & 81.2 \\
\hline $\begin{array}{ll}\text { Kinship } & \text { (friend)-based } \\
\text { neighborhood }\end{array}$ & 68.8 & 56.5 & 45.5 \\
\hline Hard to say & 34.2 & 23 & 24.7 \\
\hline
\end{tabular}

Note: in a random sample of 15 parent-accompanied migrants, our survey selected people above 15 years old who were asked to give detailed information on their sense of community in their neighborhood. Among the 15 interviewees of each group, we also excluded those migrants who provided inconsistent or untrue information. 
Table 2. General statistics for social networks and experience of the three groups (source: Yimuyuan community survey in 2013)

\begin{tabular}{|c|c|c|c|}
\hline \multirow{2}{*}{$\begin{array}{c}\text { Measurement value of } \\
\text { expectation }\end{array}$} & \multicolumn{3}{|c|}{ Migrant type (15 people in each group) } \\
\hline & $\begin{array}{c}\text { Parent-accompanied } \\
\text { migrants (above } 15 \text { old) }\end{array}$ & $\begin{array}{l}\text { Single(unma } \\
\text { rried) } \\
\text { migrants }\end{array}$ & $\begin{array}{l}\text { Couple-only } \\
\text { migrants. }\end{array}$ \\
\hline \multicolumn{4}{|c|}{$\begin{array}{c}\text { In which perspective of housing is meaningful for you to live in this neighborhood (Number } 0 \\
\text { interviewer, present } \% \text { ) }\end{array}$} \\
\hline Decent look & $3(20 \%)$ & $4(26.7 \%)$ & $7(46.7 \%)$ \\
\hline Safety & $3(20 \%)$ & $4(26.7 \%)$ & $5(33.3 \%)$ \\
\hline Accessibility to daily facilities & $7(46.7 \%)$ & $8(53.3 \%)$ & $9(60 \%)$ \\
\hline $\begin{array}{l}\text { Feeling of attachment (sense of } \\
\text { community) }\end{array}$ & $13(86.7 \%)$ & $12(80 \%)$ & $10(66.7 \%)$ \\
\hline Good community relations & $14(93.3 \%)$ & $11(73.3 \%)$ & $11(73.3 \%)$ \\
\hline \multicolumn{4}{|c|}{ Visiting neighbors (Number of interviewer, present \%) } \\
\hline Often & $6(40 \%)$ & $6(40 \%)$ & $4(26.7 \%)$ \\
\hline Sometimes & $6(40 \%)$ & $4(26.7 \%)$ & $7(46.7 \%)$ \\
\hline Seldom & $2(13.3 \%)$ & $3(20 \%)$ & $2(13.3 \%)$ \\
\hline \multirow[t]{2}{*}{ Never } & $1(6.7 \%)$ & $2(13.3 \%)$ & $2(13.3 \%)$ \\
\hline & $15(100 \%)$ & $15(100 \%)$ & $15(100 \%)$ \\
\hline \multicolumn{4}{|c|}{ Helping neighbors (Number of interviewer, present \%) } \\
\hline Often & $4(26.7 \%)$ & $5(33.3 \%)$ & $3(20 \%)$ \\
\hline Sometimes & $7(46.7 \%)$ & $6(40 \%)$ & $6(40 \%)$ \\
\hline Seldom & $3(20 \%)$ & $2(13.3 \%)$ & $4(26.7 \%)$ \\
\hline \multirow[t]{2}{*}{ Never } & $1(6.7 \%)$ & $2(13.3 \%)$ & $2(13.3 \%)$ \\
\hline & $15(100 \%)$ & $15(100 \%)$ & $15(100 \%)$ \\
\hline \multicolumn{4}{|c|}{ Reason of rich communicating experiences among neighbors (percent \%) } \\
\hline $\begin{array}{l}\text { Frequent meet in space of life } \\
\text { necessities (public kitchen, } \\
\text { laundry, bathroom, aisle) }\end{array}$ & 67.3 & 69.2 & 60 \\
\hline $\begin{array}{l}\text { Welcoming physical settings } \\
\text { (old-style front stoops of rental } \\
\text { house or adjacent sidewalks) }\end{array}$ & 78.4 & 56.8 & 55.3 \\
\hline
\end{tabular}

More than $65 \%$ of single migrants and $62 \%$ of couple migrants said they agreed with the statement that this neighborhood has high level of communal activities. Migrants' evaluations of items gauging neighborly relation are quite positive, regarding sociability, with the grand mean being $61 \%$, as associated with neighborhood acquaintance's having an average value of $58 \%$, mutual trust's average value being $55 \%$.

I asked: "is Yimuyuan an area to which you belong, or simply a place to live for a moment", $55.6 \%$ of respondents answered that Yimuyuan neighborhood can be their real home where they feel belonging and community satisfaction. In respect to the attitudes towards 'reason to stay in the Yimuyuan neighborhood', a great deal of economic advantage (cheap rent) and intimate neighborhood with kinship and friends, especially those in the areas of the working migrant class population, becomes the main consideration factor of continuing to stay in this neighborhood. Consequently, while migrants in the Yimuyuan neighborhood live a humble life, they consider the neighborhood they dwell in to be a comparatively welcoming or intimate one.

Finding: Low Living Standard But High Level of Communal Activities 
The finding indicated that migrants' spontaneously-developed housing has high level of communal activities (Figure 17, 18, 19). The reasons are listed as follows.

(1) The experience of shared functions allows communal activities to emerge or lead to increased communal activities

The space is only a physical fact, however, the functions combined with the space determine the true character of the space. Making use of functions or sharing functions supplied by the spaces are the real reasons for residents to contribute to communal activities. The communal activities occurring in the three transitional spaces mostly concern how residents use these functions. These functions become a given service that residents can share or have to share with each other.
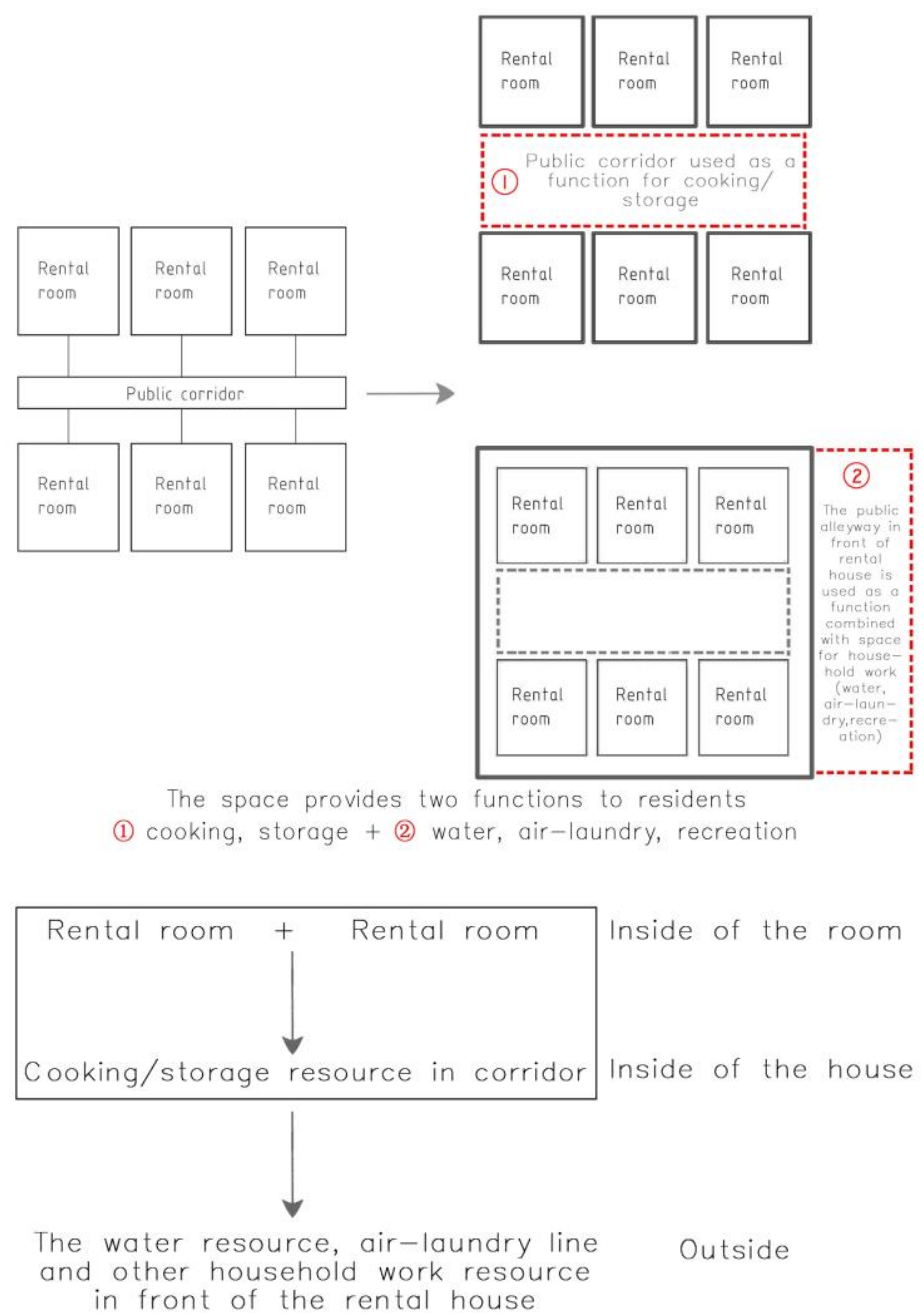

(Figure 17) Function 1 (cooking, storage) in front of the rental room and function 2 (water, airing-laundry line, household work) in front of the rental house combined with the free space available form the main characteristic of each given area. Residents use the space immediately adjacent to their rental room for the functions

Figure 17. Graphic representation of spatial changes in terms of in front of rental room and rental house in the Yimuyuan neighborhood (Drawing by author) 
it provides. The functions serve as the qualities that define the relationship between residents. This is the reason why the existence of the functions in such areas or spaces can be combined with and can be added to the number of communal activities.

The corridor is a function extension of part of its interior. When inside gets crowded, the residents go out of their rental house to continue their activities. The adjoining alleyway (in front of the rental house) becomes an extremely effective extension of the interior of the rental house. (Figure 18) The public alleyways (between the houses) are an intertwined set of daily-used function, migrant-support functions.

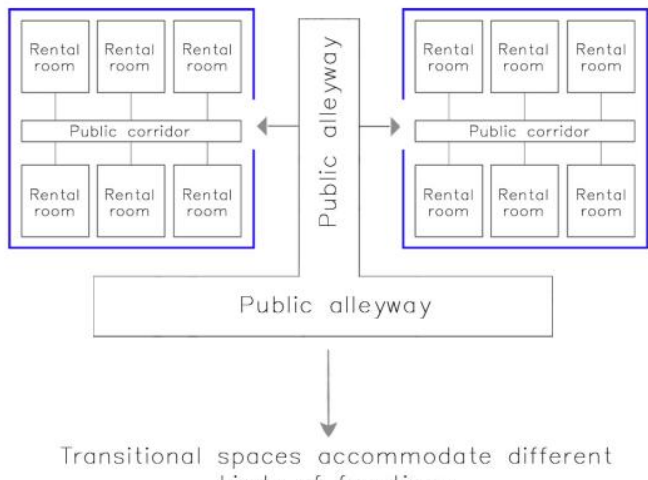
kinds of functions

Figure 18. Graphic representation of residential space as interweaving forms of functions in terms of between the rental houses (Drawing by author)

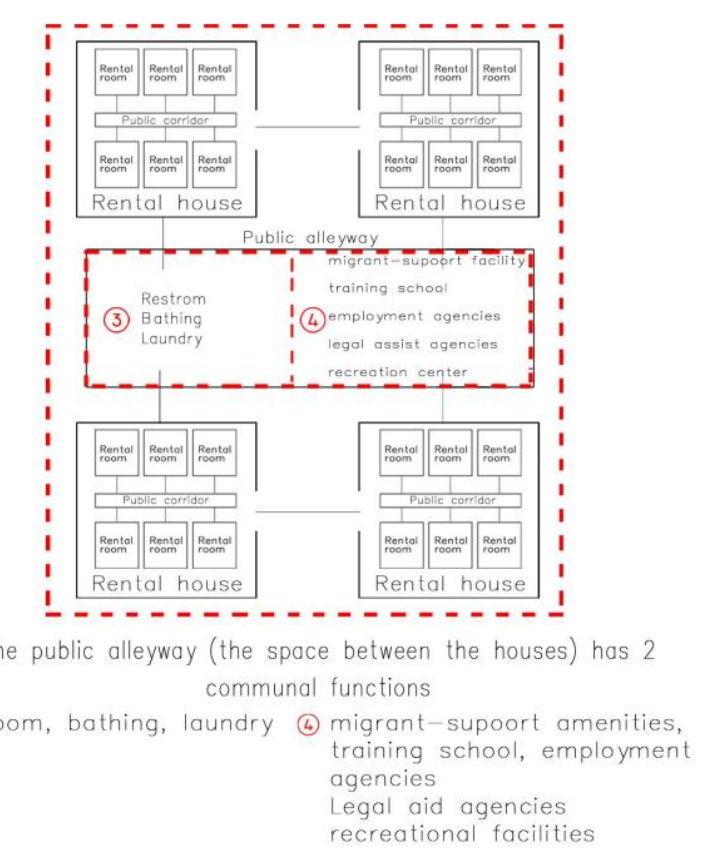

(2) Different categories of shared functions result in different communal activities

(Figure 19) Different categories of shared functions result in very different communal activities happened in the different spaces, respectively: necessary daily activities (in front of the rental 
room); commercial activities (in front of the rental house); and social service activities (between the rental houses).

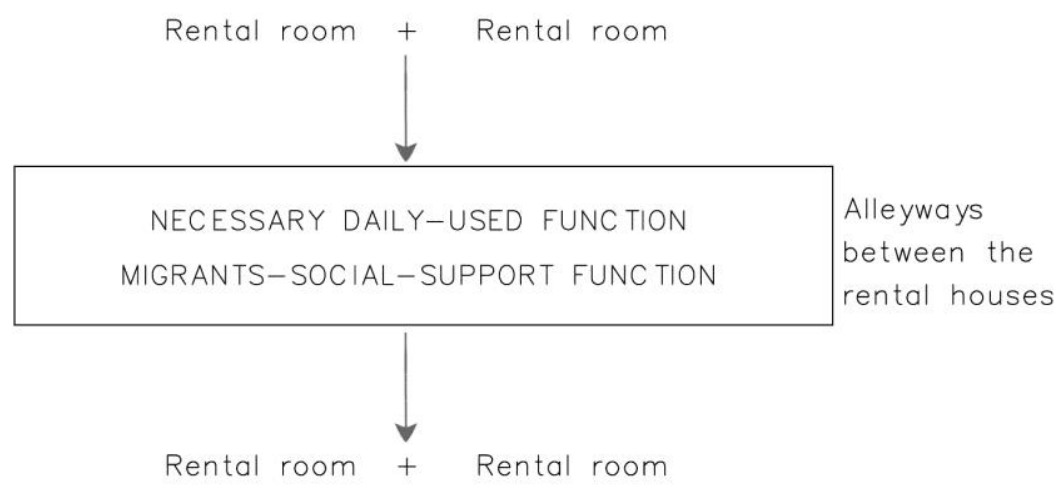

The cooking and storage shown in the corridor; water source, airing-laundry line and household work like working in the alleys in front of the house; daily-used shared facilities and communal used services performed in the space between the rental housesall these functions or facilities and services, provide a medium by which communal activities are actualized.

(3) Shared experiences develop three types of relationships that support continuity of migrants' 'way of life'

Shared experiences develop three types of relationships, namely, the relationship between residents and the space, the relationship of residents to the function of their choice, and the inter-personal relationship among residents. Rural-to-urban migrant residents are physically living in a decayed neighborhood, but they are satisfied to live in so-called shantytown areas as they feel a strong 'sense of belonging' to their area. Their physical decayed neighborhood generates its learned 'way of life' which is shared by rural migrant residents. And this subculture matches their inherent lifestyle, and it receives their appreciation and energy which both offset the difficulties presented in the decayed accommodation.

(Figure 20) There is considerable connection in the kinds of ties which are obtained: relatives are often neighbors; mutual help in household activities is both possible and frequent; and the various ties become intertwined through many activities within the neighborhood. To reiterate, the spatial functions are more than a physical, environmental issue; it is the concern of the sharing of experiences among rural-to-urban migrant residents and by which their communal activities can be located. Concretizing the argument, the low-rent housing for rural migrants should differ from the conventional housing.
Figure 19. Graphic representation of residential space as interweaving forms of functions in terms of between the rental houses 
Figure 20. Spatial elements in horizontal and vertical format in Yimuyuan neighborhood (Drawing by author)

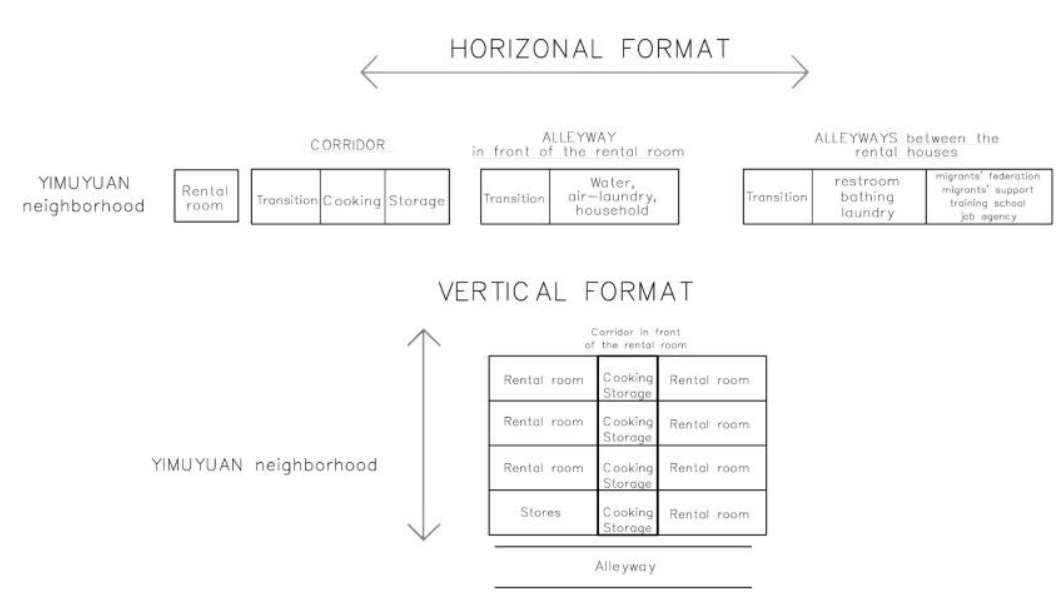

\section{LOW-RENT HOUSING SHOULD DIFFER FROM THE CONVENTIONAL HOUSING}

Without professional design, it has been presented that the migrants' spontaneous-developed Yimuyuan neighborhood has succeeded in making a low-rent neighborhood with close-knit communal activities. However, the contemporary low-rent housing is: dwelling units contain the full range of functions for individual use, and shared functions are absent in the transitional spaces. Planners and designers provide functions and services grounded on middle-class values and use these values to solve migrants' difficulties and improve their residential conditions. The rural-to-urban migrant residents prefer to live in high enough densities so that many related families could live near each other and are satisfied to live in so-called slum areas. Chinese migrant residents' lifestyle cannot be changed simply by presenting it with middle-class services, such as open space, ground garden and peaceful environment.

Proposed approach to housing migrant residents in low-rent housing

Based on the study, I propose three strategies that are compared to the contemporary low-rent housing:

Cut the size of each private dwelling unit; simplify the functions in each private unit

For single family homes we go to the 2006 International Residential Code. It states that each dwelling unit shall have at least one room with a minimum of 11.1 square meters. In current major contemporary low-rent housing, the size of each type of rental room is far greater than what is needed to be comfortable. Compared to the standard residential unit, the private units are smaller because only functions such as sleeping and personal hygiene are kept inside the private unit, and the other functions 
(cooking, dining, resting) are relocated outside the private unit. Typical rental units have simplified functions into two parts: 1 . Bedroom; 2. Restroom. This is because using communal spaces and shared functions decrease the repetitive need to use the same functions individually. Acceptable compactness as a feature can be one of the finest methods to attain sustainability, low cost and finally more low-rent dwelling units can be created. By sharing such functions, people living in low-rent housing have access to many more facilities than they would on their own.

(2) Increase the size of the communal spaces for the shared functions and enrich the functions for the sake of migrant residents.

Compared to the standard corridor, there are more shared functions within the space, but shared functions differ according to the location of the transitional spaces (for example, corridors on upper floors, halls on ground floors, and streets between the rental houses). Regarding the strategies using shared functions, the following shared functions comprise the basis for designing low-rent housing for rural-to-urban migrants in China: hygiene and sanitary functions; cooking and dining functions; storage and rest functions; social service and education functions; and recreation and hobby functions.

(3) The transitional communal spaces within the neighborhood ought to serve more than one main function in order to make residents show up at different times by using different functions combined with different spaces. The 'collaborated communities' 'central living' and 'housing with (more) shared functions' will comprise the future low-rent housing I propose. It can be as 'housing that features spaces and facilities for joint use by all residents who also maintain their independent living'.

\section{CONCLUSION}

This study investigates rich communal activities in low-rent housing for Chinese rural-to-urban migrants through an examination of the intermediary spaces combined with functions shared among such Chinese migrants in their urban settlements. Such functions are to help rural migrants with the process of managing their spatial transition from the rural setting to the urban setting. Chinese migrants gradually transfer from their home rural settlements to establish city lives and engage in urban occupations, but their sense of identity and family network remain grounded in a village culture. The high level of communal activities found in the spontaneous urban settlements of rural-to- 
urban migrants, can be understood as one aspect of the adherence to the lifestyle of their rural settlements.

The typing should be Analysis of the migrants' spontaneouslydeveloped housing in the Yimuyuan case suggests two points. Firstly, the high level of communal activities occurring appertains to residents using the shared functions. These functions become a given condition that residents can share with other residents. Secondly, all these shared functions provide a medium by which communal activities are actualized. The available shared functions help to build up the relationship of residents to the functions of their choice, and also make it possible to generate communal activities among residents.

Therefore, the results of this study reveal that housing typology (low-rise or high-rise) is not fundamental in influencing the high or low level of communal activities. If low-rent neighborhoods are rich in communal activities, this is not because they are crowded or are more suitable places, but because they have sufficient functions to allow that sharing to take place. The same can be applied to places which have few communal activities, it is not resulting from a lack of people or open places, but it is caused by the absence of functions that can be shared, thereby preventing the occurrence of communal activities.

Finally, I defend this study that the role played by the transitional spaces must be joined with functions that residents can share or must share with each other. The shared functions situated in the transitional spaces actually allow communal activities to take root. Founded on concepts of the person-to-environment relationship in terms of communal activities, the study emphasizes that low-rent housing has an explicit role to play for each rural migrant, since every individual develops a different emotional connection with the environment and with the other migrants. Therefore, the different categories of shared functions form not only communal shared activities among migrant residents, but also develop diverse relationships between residents and their low-rent housing as they adjust to new environments in their destination cities.

\section{ACKNOWLEDGEMENT}

First of all, I would like to express my heartfelt gratitude to the administration office of Seoul National University and to the National Institute for International Education (NIIED) who granted me a Korean government scholarship. 
I am indebted to all my friends in South Korea and in China for their personal support during a challenging period. Their academic and personal advice and positive comments were a large contributory factor to my finishing of my doctorate.

\section{REFERENCE}

Beja, J. P., \& Bonnin, M. (1995). The Destruction of the" Village". China Perspectives(2), 21-25.

Bray, D. (2005). Social space and governance in urban China: The danwei system from origins to reform: Stanford University Press.

Cai, F. a. L., Y. F. (eds.). . (2001). Ways and channels of Chinese migration (1990-1999). Beijing: Social Science Literature Press.

Canter, D. (1977). The psychology of place (London): Architectural Press.

Chan, K. W., \& Zhang, L. (1999). The hukou system and rural-urban migration in China: Processes and changes. In J. Logan (Ed.), The China Quarterly (Vol. 160, pp. 818-855).

Chen, T. a. Z., X. (1998). Micro-analysis of the development of the floating people's settlement-empirical investigation of the development of the liudong renkou's enclaves in Beijing. (Unpublished manuscript), Chinese Academy of Sciences.

Chung, H. (2013). Rural transformation and the persistence of rurality in China. Eurasian Geography and Economics, 54(5-6), 594-610.

Fan, C. C. (2002). The elite, the natives, and the outsiders: Migration and labor market segmentation in urban China. Annals of the Association of American Geographers, 92(1), 103-124.

Gans, H. J. (1962). The urban villagers: Group and class in the life of Italians-Americans: [New York]: Free Press of Glencoe.

Graves, N. B., \& Graves, T. D. (1974). Adaptive strategies in urban migration. Annual Review of Anthropology, 3(1), 117-151.

Jie, F., \& Taubmann, W. (2002). Migrant enclaves in large Chinese cities. In J. R. Logan (Ed.), The new Chinese city: Globalization and market reform (pp. 181-197).

Li, S.-m., Zhu, Y., \& Li, L. (2009). Community type, gateness and neighbourhood experiences: A study of Guangzhou, China: Centre for China Urban and Regional Studies, Hong Kong Baptist University.

Li, S.-m., Zhu, Y., \& Li, L. (2012). Neighborhood type, gatedness, and residential experiences in Chinese cities: A study of Guangzhou. Urban Geography, 33(2), 237-255.

Lipman, A..(1971). Professional ideology:'community'and'total'ar chitecture. Architectural Research and Teaching, 39-49.

Piante, C. a. Z., H. B. . (1995). A law onto itself-Beijing's Zhejiang village. China Perspectives(2), 2-15.

Read, B. L. (2003). Democratizing the neighborhood? New private housing and home-owner self-organization in urban China. The China Journal(49), 31-59. 
Sarason, S. B. (1974). The psychological sense of community: Prospects for a community psychology: Jossey-Bass.

$\mathrm{Su}$, P. (1996). The evolution of Chinese peasant communication model", Shehui Kexue Zhanxian. Social Science Front(82).

Tian, L. I. (2008). The chengzhongcun land market in China: Boon or bane?-A perspective on property rights. International Journal of Urban and Regional Research, 32(2), 282-304.

Whyte, M. K. a. P., W. L. . (1984). Urban Life in Contemporary China. Chicago: University of Chicago Press.

Whyte, W. F. (1943). Street corner society: The social structure of an Italian slum: University of Chicago Press.

Wu, F. (2012). Neighborhood attachment, social participation, and willingness to stay in China's low-income communities. Urban Affairs Review, 48(4), 547-570.

$\mathrm{Wu}, \mathrm{W}$. (2002). Temporary migrants in Shanghai: housing and settlement patterns. In L. J. R. (Ed.), The new Chinese city: Globalization and market reform. Oxford: Blackwell Publishers.

Xiang, B. (1993). Beijing has a Zhejing village-a study on spontaneous social transition of urbanization. Shehui Xue Yu Shehui Diaocha [Sociology and Social Survey], 3, 68-74.

$\mathrm{Xu}, \mathrm{A}$., Xie, X., Liu, W., Xia, Y., \& Liu, D. (2007). Chinese family strengths and resiliency. Marriage \& Family Review, 41(12), 143-164.

$\mathrm{Xu}, \mathrm{F}$. (2008). Gated communities and migrant enclaves: the conundrum for building 'harmonious community/shequ'. Journal of contemporary China, 17(57), 633-651.

Yu, J. a. Y.X. (2013). Changes in the Determinants of Marriage Entry in Post-Reform Urban China. Retrieved from

Zhang, L., Zhao, S. X., \& Tian, J. (2003). Self-help in housing and chengzhongcun in China's urbanization. International Journal of Urban and Regional Research, 27(4), 912-937.

Zhu, Q., \& Wu, H. (2003). The cultural role and perception of agriculture in China. Paper presented at the the Roles of Agriculture International Conference. Rome, Italy. 